\title{
DE SCHRIJFDOOS KANNON MET DE WILGENTAK
}

Generaal J.C. Pabst (1873-1942), de toenmalige Nederlandse gezant in Japan, kocht de schrijfdoos Kannon met de Wilgentak op 8 januari 1940 van een zekere Kishima. In zijn persoonlijke collectienotities noemt Pabst 'de schilderij van Kanō Hōgai, School voor Schoone Kunsten te Tokyo' als 'klaarblijkelijke' inspiratiebron voor de schrijfdoos. Waarschijnlijk heeft hij deze schildering alleen gezien op afbeeldingen in de boeken waarnaar hij verwijst. Dit valt te begrijpen aangezien de Kunstuniversiteit in Tokyo (de opvolger van 'de School voor Schoone Kunsten') pas sinds 1999 over een openbaar museum beschikt. Pabst betaalde 600 yen voor de doos, die een van zijn laatste kunstaankopen is geweest.

\section{Ontwerp}

Kannon, de bodhisattva van mededogen, zweeft in de lucht en lijkt door wolken te worden meegevoerd ( $\mathrm{afb}$. 1). Toch breken er tegelijkertijd golfjes tegen haar lotusmuiltjes aan. Er dwarrelen enkele lotusbloembladeren naar beneden. De blik is naar beneden gericht. Kannon (in het Sanskrit: Avalokiteshvara, in het Chinees: Guanyin) heeft een wilgentak in de linkerhand en een flesje waaruit vloeistof stroomt in de rechterhand. Over het losse gewaad draagt zij een transparante sluier. Opvallend is de rijkdom aan sieraden. Haar hoofd en gestalte worden elk omgeven door een nimbus.

De wolken zetten zich niet alleen voort op de zijkanten van de schrijfdoos, maar eveneens op de binnenkant, zowel op de bodem als op de binnenkant van het deksel (afb. 3). Tussen de wolken is daar een water met talrijke lotusplanten te zien; de rand van sommige bladeren wordt omgeslagen door een zuchtje wind. Een enkel blad is aan het verdorren en buigt zich naar het wateroppervlak. Verspreid staan lotusbloemen, in knop of in volle bloei, en tevens een enkele kale zaaddoos. Ook hier dwarrelen lotusbloembladeren naar beneden, die, net als de wolken, duiden op een eenheid van de voorstelling op de buiten- en binnenkant. Een halfopen raamwerk draagt de inktsteen en de waterdruppelaar. De fraaie zilveren waterdruppelaar heeft de vorm van een handtrommel en een fluit die op een lotusblad liggen. Volgens een van de legendes bezocht Kannon de onderwereld. Daar betoonde hij/zij (want het geslacht kon wisselen of dubbelzinnig blijven) groot mededogen met de verdoemden, waarna plotseling een regen van lotus neerdaalde en de verworpenen werden bevrijd. Vervolgens begaf Kannon zich op een lotusbloem naar het Lotus Paradijs Eiland Poo Too. Wellicht werd de aankomst begeleid door muziek van fluit en trommel. Dit verhaal lijkt het thema van deze schrijfdoos te zijn. 


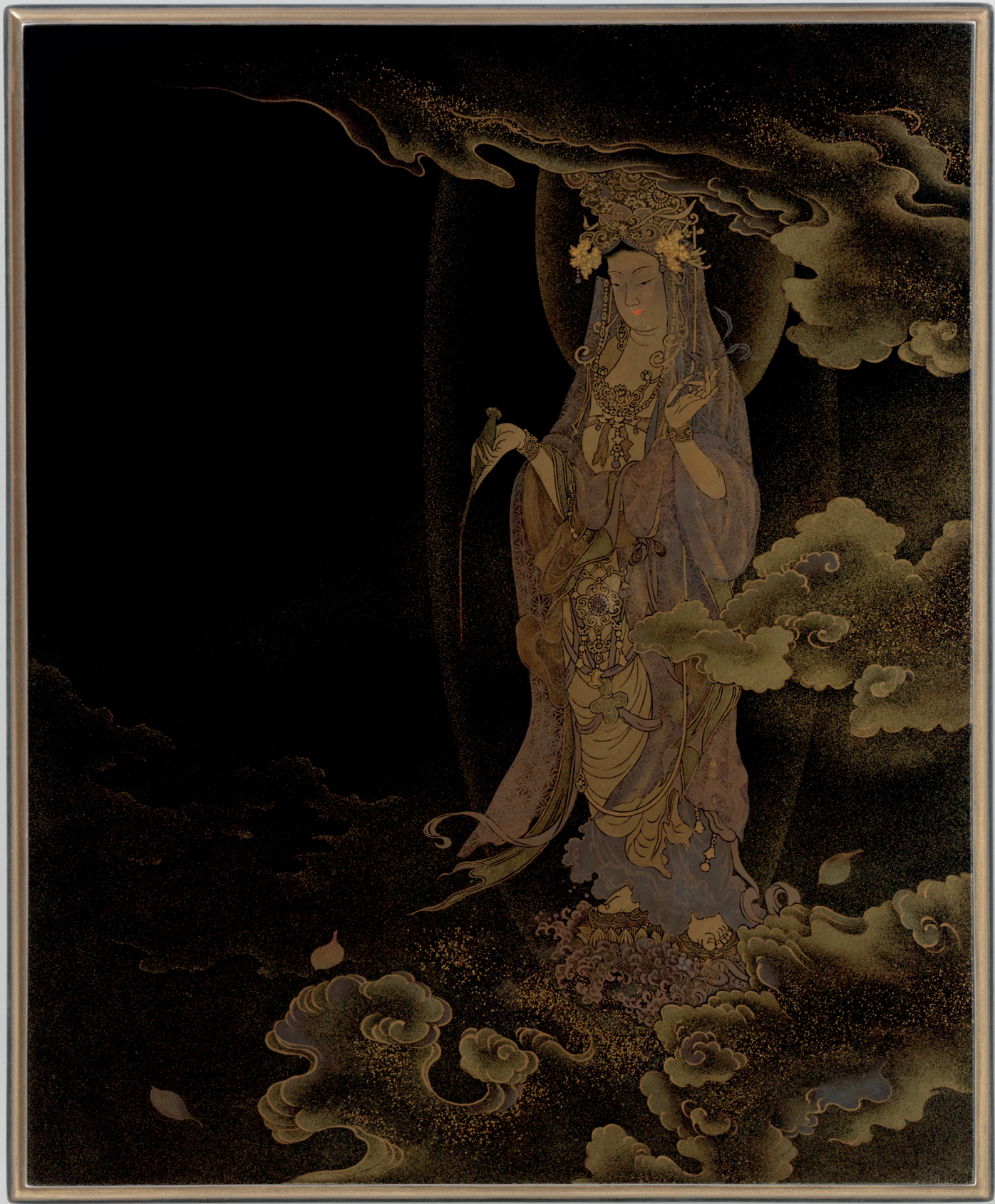

Afb. 1

Buitenaanzicht van de schrijfdoos Kannon met de Wilgentak, 22,9 x 18,7 x 4,3 cm., Japan, ca. 1890-1900, Rijksmuseum Amsterdam, inv.nr. AK-C-2012-13, bruikleen Jan Dees \& René van der Star 
Afb. 2

De schildering

Avalokiteshvara als een

Barmhartige Moeder

door Kanō Hōgai (1828-

1888), 195,8 x 86,1 cm.,

Japan, 1888, Museum

van de Kunstuniversiteit in Tokyo

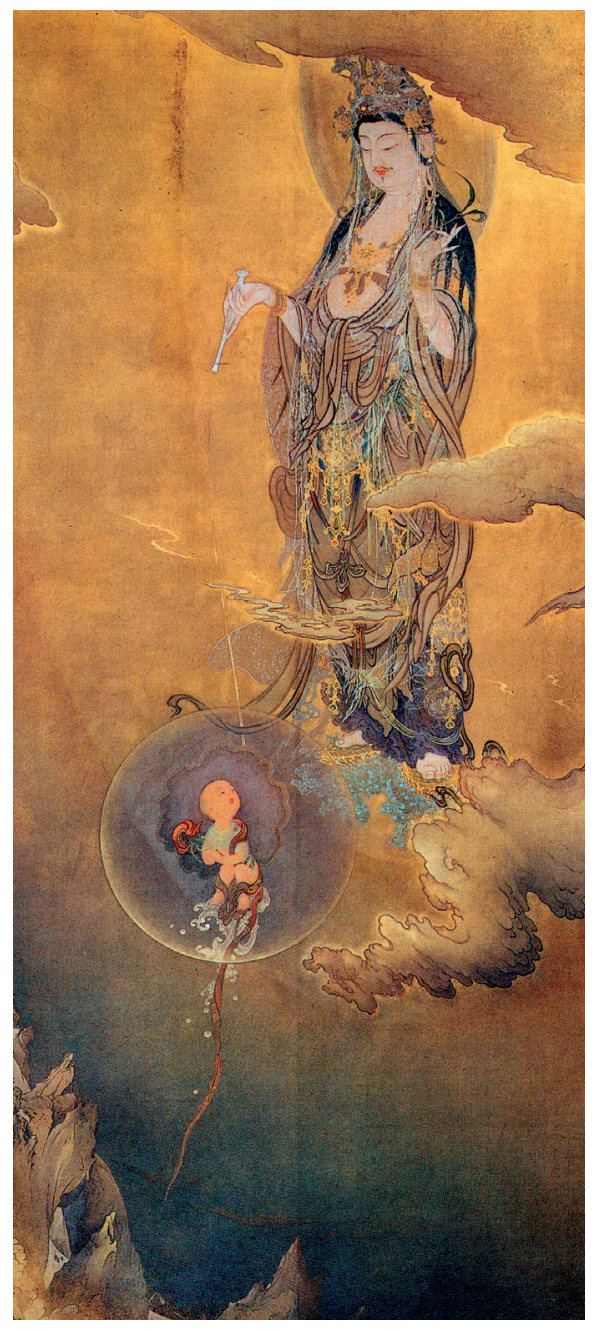

Waarom Pabst de voorstelling in verband bracht met een schildering van Kanō Hōgai (1828-1888) wordt in één oogopslag duidelijk bij het zien van de schildering Avalokitesvara als een Barmhartige Moeder uit 1888 (afb. 2). De figuur van Kannon en de vorm van de wolken tonen grote gelijkenis met die op de lakdoos. Toch bestaan er ook opmerkelijke verschillen. Op de schildering toont Kannon, ondanks de titel, mannelijke trekken met een snor en een klein sikje. De meest opvallende verschillen zijn de zwevende baby in een ronde halo en het diepe ravijn daaronder.

Men zegt dat de schilder tot deze voorstelling is gekomen omdat hij de liefde van een moeder voor haar kind als de hoogste uiting van menselijke compassie beschouwde. Op deze wijze wordt Kannon, de bodhisattva van het mededogen, als het ware 'geladen' met het fenomeen moederliefde. Bovendien wordt het thema in verband gebracht met het recente overlijden van Hōgai's vrouw, die hij Kannon-sama(!) placht te noemen, en het overlijden van hun kleinzoon, die model zou hebben gestaan voor het kind op de schildering. In Japan wordt dit onvoltooid gebleven werk van Hōgai

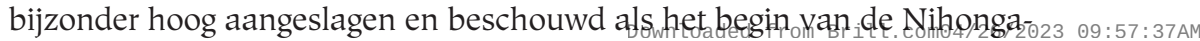


Afb. 3

De binnenkant van de schrijfdoos met de inktsteen en de waterdruppelaar op een halfopen raamwerk. Lakdecoratie met lotusplanten in het water, omgeven door wolken en nevelslierten

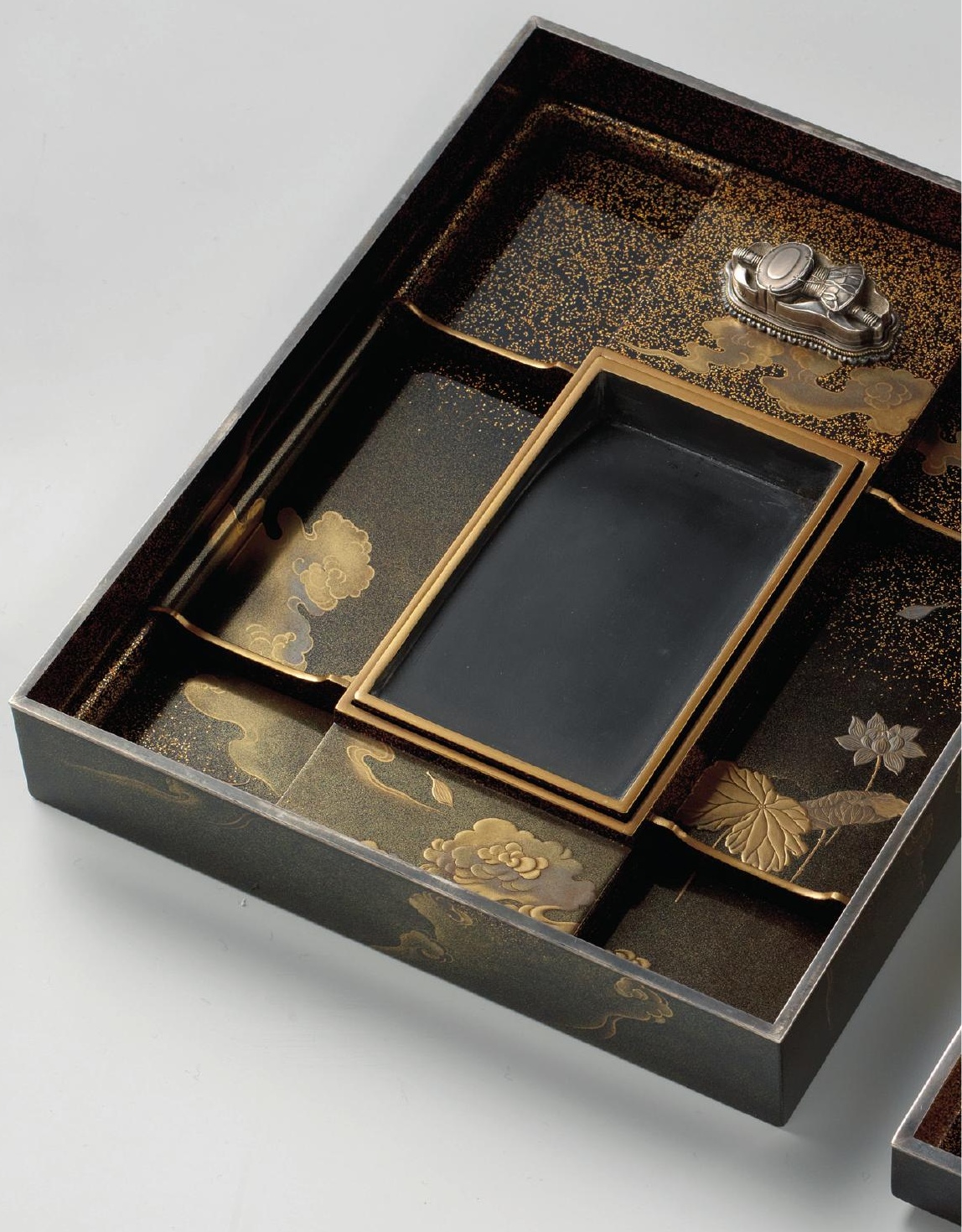




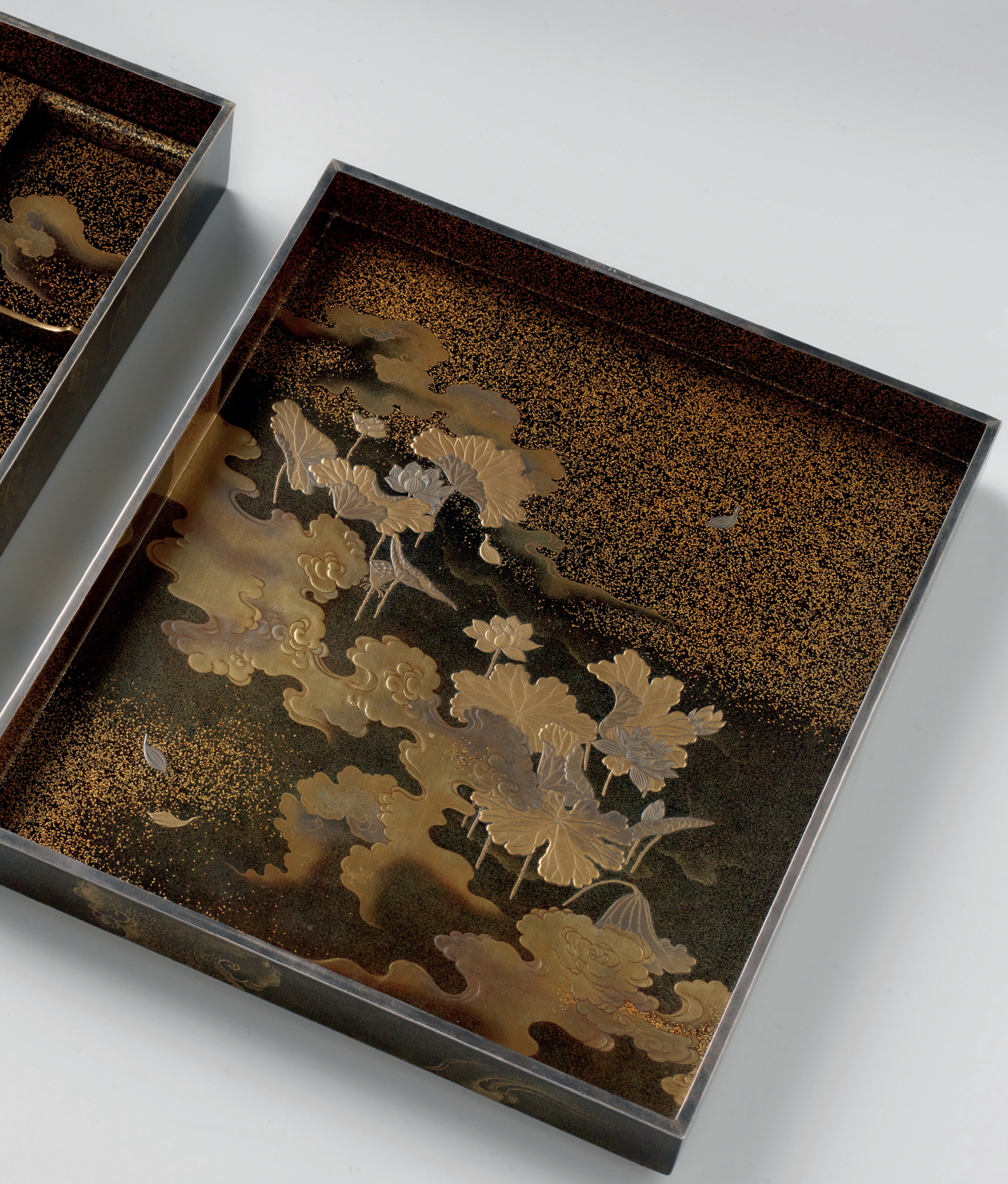



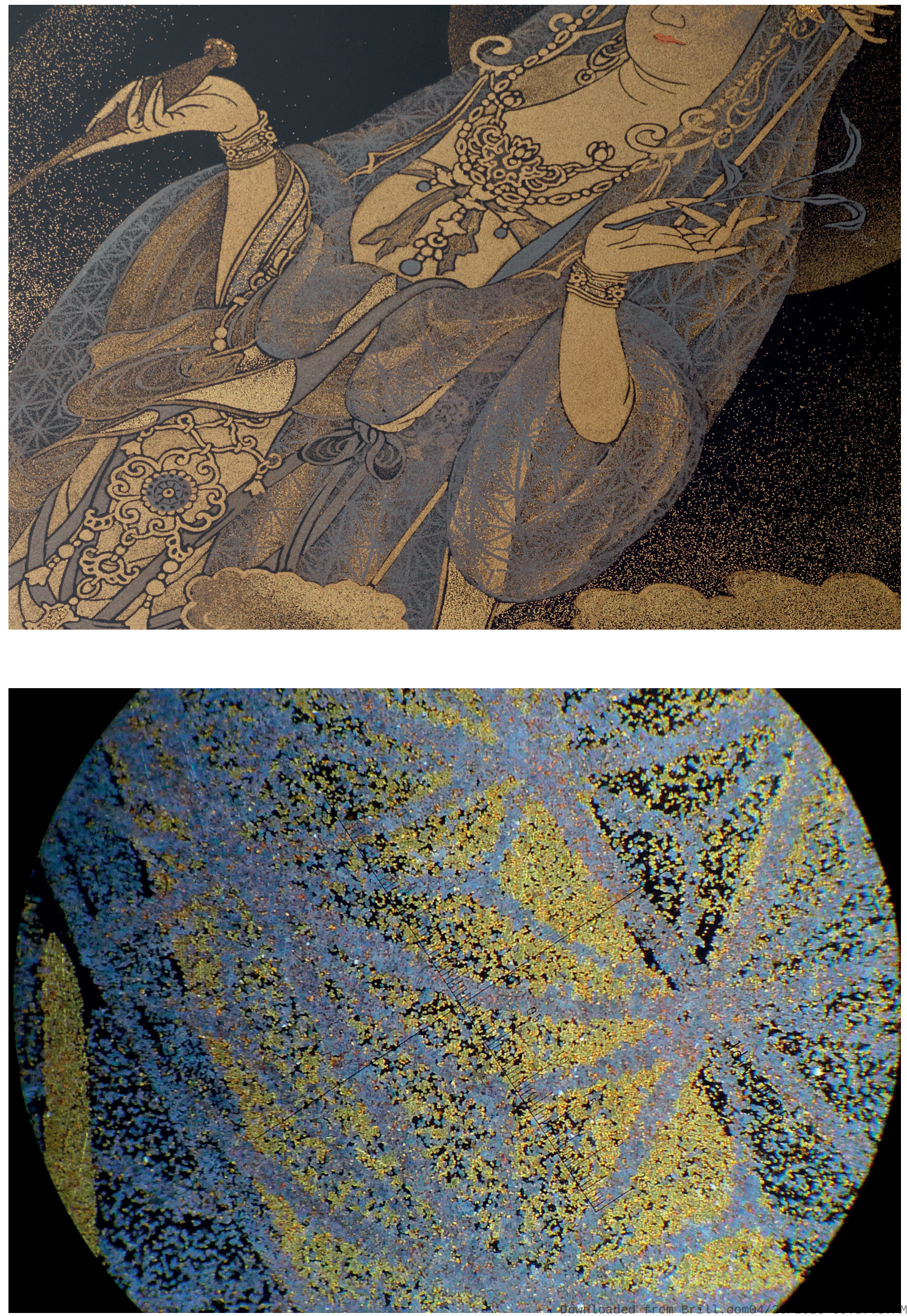
Afb. $4 a$

Detail van de kleding

Afb. 4 b

In sterkere

vergroting blijkt dat

de doorschijnende

zilveren sluier met een

dun penseel over de

andere kleding heen is

geschilderd schilderstijl. De lakmeester heeft er weliswaar zijn inspiratie aan ontleend, maar heeft het tegelijkertijd omgevormd tot een ander thema. Over de mogelijke reden daarvoor komen wij later nog te spreken.

\section{Laktechnieken}

De voorstelling op de buitenkant is in zijn geheel uitgevoerd in de 'uitgeslepen' togidashi techniek op een zwarte ondergrond. ${ }^{1}$ De figuur van Kannon is tot in de kleinste details uitgewerkt met alle plooien van de kledij, de ingewikkelde haartooi en de verfijnde sieraden, maar de wolken en de nevelsluiers zijn veel globaler weergegeven. De lakmeester heeft vooral gebruik gemaakt van goudpoeder (en op enkele plaatsen goudsnippers), aangevuld met zilverpoeder. Het virtuoze strooiwerk geeft blijk van groot meesterschap. Het enige kleuraccent wordt gevormd door de felrode lippen van Kannon.

Jarenlang heb ik mij het hoofd gebroken over de wijze waarop het doorschijnende zilveren overkleed met het sterrenpatroon (asa no ha) tot stand gekomen moet zijn. Indien alle kledij eerst in hiramakie zou zijn opgebouwd zou het ragfijne overkleed bij het terugslijpen met de steentjes weg gewreven zijn. Hoe dan wel? Sterke vergroting van een kledingdetail van Kannon laat duidelijk zien dat de doorschijnende zilveren sluier met een dun penseel op de andere kledij geschilderd is ( $a f b .4 a$ en $4 b$ ). Dit moet gebeurd zijn nadat de voorstelling in togidashi helemaal voltooid was. Omdat een doorschijnend effect moest worden bereikt was het in dit geval niet bezwaarlijk dat een enkele laag zilver slechts een beperkt dekkend vermogen heeft.

De halo's rond het hoofd en de figuur van Kannon zijn eerst in zwarte of transparante lak aangebracht en vervolgens aan de buitenbegrenzing dicht met goudpoeder bestrooid en naar binnen toe steeds spaarzamer (bokashi). De lotusplanten, de wolken en nevelslierten op de binnenkant zijn weergegeven in de drie belangrijkste makie-technieken: hoogreliëf takamakie, laagreliëf hiramakie en teruggeslepen togidashi. Aangetekend moet worden dat het in het voltooide object vaak niet meer precies valt uit te maken waar hiramakie eindigt en takamakie begint (afb. 5).

De donkere velden die dunnetjes met goudpoeder zijn bestrooid vertegenwoordigen het water waarin de lotusplanten groeien; de gebieden aan weerskanten die dicht bestrooid zijn met goudsnippers moeten dan de oevers verbeelden (afb. 5).

\section{Datering}

Het enige vaste punt in de datering vormt het jaar 1888, waarin Kanō Hōgai stierf. De schildering was onvoltooid gebleven. Uit allerlei details blijkt dat het ontwerp van de buitenkant van de schrijfdoos op deze schildering is gebaseerd en niet op een vroegere versie van Avalokiteshvara als een Barmhartige Moeder uit 1883, die zich in de Freer Art Gallery te Washington bevindt.

De schildering uit 1888 is altijd bewaard in de Kunstacademie van Tokyo

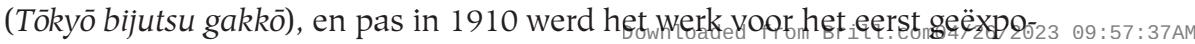




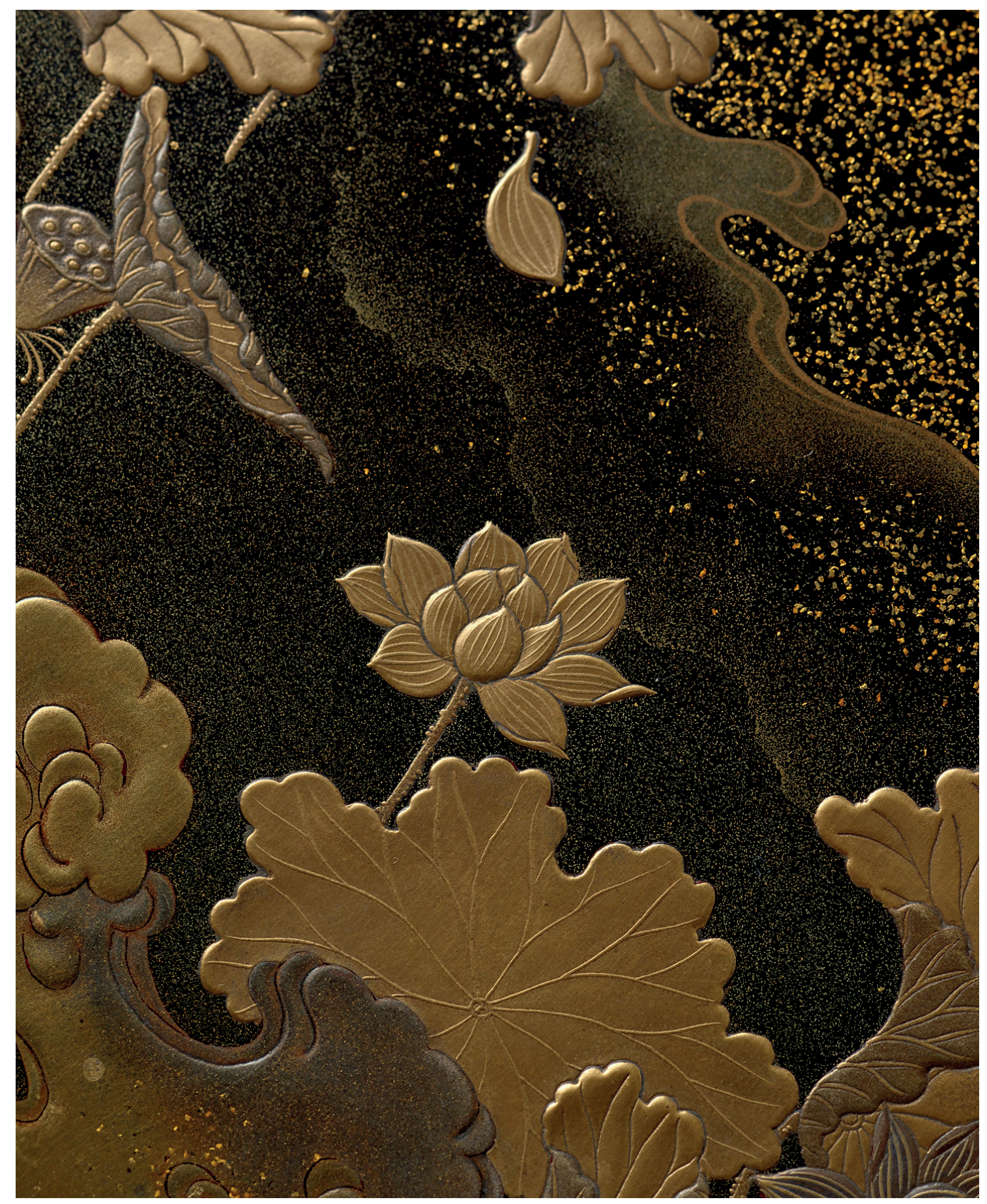

Afb. 5

Detail van de binnenkant met lotusplanten in het water vlakbij de oever in een scala aan makie technieken 
seerd. De binnenindeling van de schrijfdoos met het halfopen raamwerk lijkt van vóór 1900 te dateren, omdat in het begin van de 20 eeuw gewoonlijk een gesloten plankje werd gebruikt om de inktsteen en de waterdruppelaar te dragen. ${ }^{2}$ Daarom is de meest voor de hand liggende mogelijkheid dat de lakdoos is gemaakt door een lakmeester van de Kunstacademie, die toegang tot de schildering had. Als de uitgesproken meester van het togidashi komt Shirayama Shōsai (1853-1923) dan in aanmerking, die van 1891 tot 1893 professor aan de academie was en daarna opnieuw van 1905 tot 1923. Het is minder waarschijnlijk dat de schrijfdoos in de tweede periode is vervaardigd, aangezien hij toen inmiddels zijn karakteristieke verfijnd gestileerde en tamelijk kleurrijke stijl had ontwikkeld. Veel waarschijnlijker stamt het werk uit de periode 1890-1900, toen Shōsai zijn thema's wel vaker op schilderingen baseerde.

Maar waarom zou een lakkunstenaar van het formaat Shirayama Shōsai, die zich bovendien graag liet voorstaan op zijn individualiteit, dan nagelaten hebben om het werk te signeren?

\section{Verpakkingsdoos}

Zelfs op de houten verpakkingsdoos is geen signatuur van de maker te vinden, en een titel van het werk al evenmin. De titel Kannon met de Wilgentak is daarom slechts een beschrijvende en toegekende titel, zoals De Nachtwacht dat is voor Rembrandts beroemdste schilderij (afb. 6).

\footnotetext{
Afb. 6

De houten verpakkingsdoos, waarop in goudlak geschreven staat: Sokubutsu Shin-in sama on suzuribako. Tevens zijn allerlei inscripties en stickers van verzamelaars, handelaren en veilinghuizen te zien
}

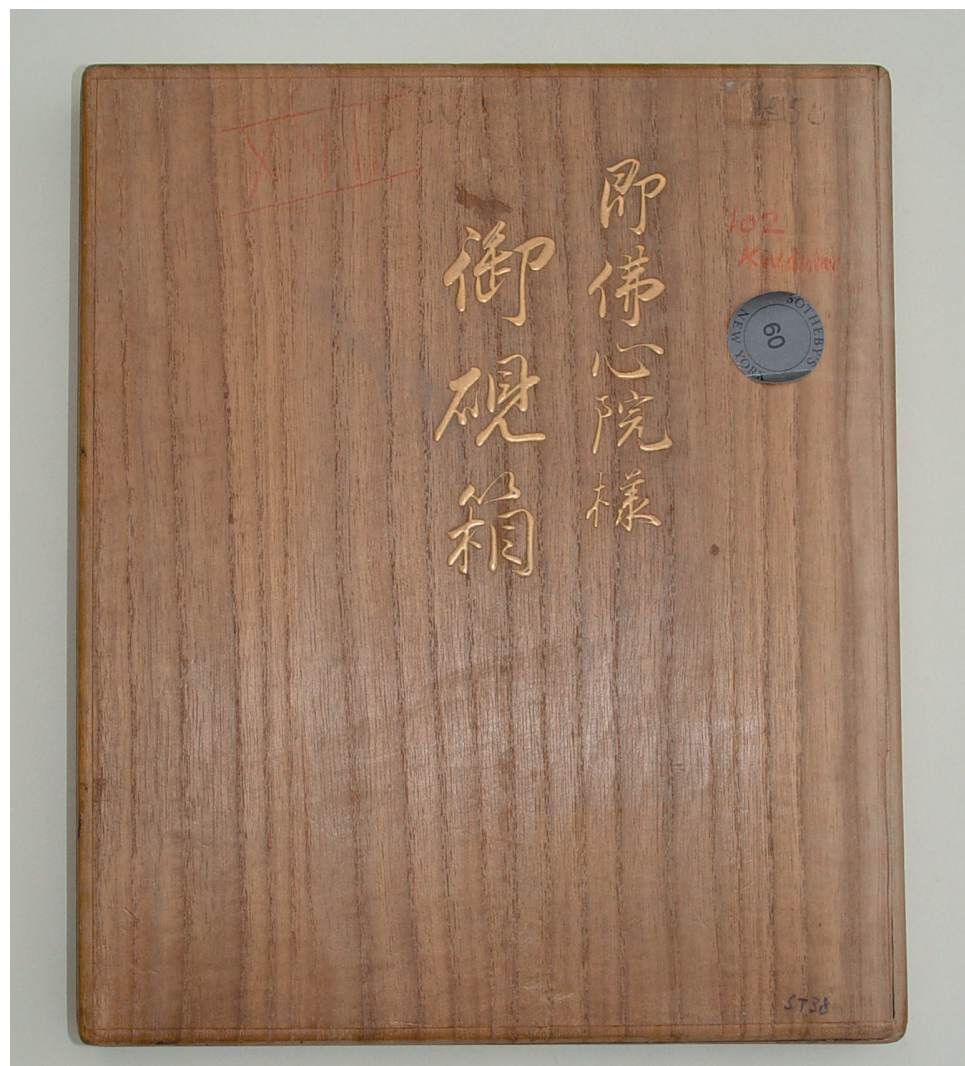


$\mathrm{Nu}$ staat er wel een tekst op het deksel van de verpakkingsdoos, niet zomaar in zwarte inkt, maar zelfs in goudlak: Sokubutsu Shin'in sama on suzuribako. Deze tekst zegt dat deze schrijfdoos in het bezit is geweest van de hooggeplaatste boeddhistische monnik (of non) met de naam Shin'in. Zou de schrijfdoos dan misschien speciaal voor deze kloosterling gemaakt zijn? In dat geval is het niet zo verrassend dat de lakkunstenaar zijn signatuur niet op het werk heeft achtergelaten, zoals dat ook minder gebruikelijk was op een werk dat voor de keizer was bestemd. Dan wordt wellicht ook begrijpelijk waarom de lakmeester het ontwerp Avalokiteshvara als een Barmhartige Moeder heeft omgevormd van een thema met tamelijk particuliere gevoels-waarde voor de schilder tot een meer algemeen religieus thema voor de kloosterling. ${ }^{3}$ Toch zijn dit niet meer dan veronderstellingen, en blijft de toeschrijving aan Shirayama Shōsai speculatief.

\section{Pabst}

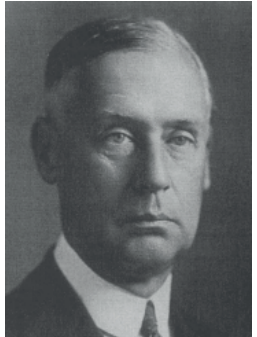

Afb. 7 Generaal Jean Charles Pabst (1873-1942)
Gedurende bijna 20 jaar (1923-1942) was generaal Pabst de Nederlandse gezant in Japan (afb. 7). Vóór 1940 was Nederland nog niet met ambassadeurs in het buitenland vertegenwoordigd, maar met gezanten. Pabst was de Japanse taal machtig en nam binnen het corps diplomatique een vooraanstaande plaats in. Van 1910 tot 1916 was hij al militair attaché in Japan en China geweest. Bij het uitbreken van de Pacific War (december 1941) kwam de gezant onder huisarrest te staan, maar van de oorlog zelf heeft hij niet al te veel meegemaakt aangezien hij zes weken na het uitbreken ervan, op 24 januari 1942, plotseling is overleden. ${ }^{4}$

Pabst moet een verwoed kunstverzamelaar zijn geweest. Dat ging niet altijd van een leien dakje, want bij de grote aardbeving, die Tokyo en Yokohama op 1 september 1923 trof, is zijn fraaie collectie Blanc de Chine volledig verloren gegaan. In Japan is Pabst naast keramiek ook prentbriefkaarten, Nagasaki prenten, netsuke, zwaardsieraden en lakwerk gaan verzamelen. Een deel ervan is na de oorlog naar Nederland gebracht, waar de netsuke en het lak in bezit kwamen van zijn neef Dr. A.A.H. Stolk. Toen deze burgemeester van Zeist was heb ik daar, tijdens een studiemiddag van de Vereniging voor Japanse Kunst in 1975, onder meer de schrijfdoos Kannon met de Wilgentak mogen bewonderen. In de jaren 1983/1984 is het lakwerk bij Kunsthandel Klefisch in Keulen geveild, waarna de schrijfdoos naar de Verenigde Staten verdween. De doos dook weer op in de catalogus van een veiling, die Sotheby's New York had gepland op 20 september 2001. Door de aanslag op de Twin Towers van 11 september moest de veiling worden uitgesteld tot 16 oktober, maar toen lukte het toch om de schrijfdoos Kannon met de Wilgentak op een dramatisch slecht verlopende veiling (61\% onverkocht) voor een torenhoge prijs te verwerven. Omdat het reguliere vliegverkeer op New York nog niet was hervat, heeft het nog vijf weken geduurd voordat de doos bij ons arriveerde. 


\section{Literatuur}

Jan Dees, 'Shirayama Shōsai, Japanese Lacquer Artist (1853-1923)', Arts of Asia 32/2 (2002), pp. 92-105.

Kano Hogai, the Track to Avalokitesvara as a Merciful Mother (catalogus). Tokyo University of Arts, 2008.

Persoonlijke aantekeningen van Pabst over zijn collectie lakwerk en netsuke (als fotokopie in mijn bezit).

A.A.H. Stolk, Jean Charles Pabst, Diplomaat en Generaal in Oost-Azië 1873-1942, 1997. [Privé-uitgave door de auteur.]

\section{Noten}

1. Aziatische Kunst 44/3: 12-4.

2. Zie drie voorbeelden in Aziatische Kunst 44/2, 44/3 en 44/4.

3. Sokubutsu Shin'in is een religieuze naam (ingo) die niet alleen van een monnik of non geweest kan zijn, maar ook wel van iemand uit de hoge aristocratie die zich uit het openbare leven heeft teruggetrokken.

4. De zeer drukbezochte Engelstalige uitvaartdienst in Tokyo kreeg een bijzondere ontknoping. Ambtenaren van de Nederlandse legatie hadden van de Japanse autoriteiten toestemming gekregen om aan het slot een gezang uit het liedboek van de Nederlands Hervormde Kerk in het Nederlands te zingen. Zij hadden er niet bij gezegd dat dit het Wilhelmus betrof. Zo kon het gebeuren dat in oorlogstijd het corps diplomatique, de Japanse ministers en autoriteiten en honderden andere aanwezigen aan het einde van de plechtigheid staande naar het Nederlandse volkslied hebben geluisterd. 